\title{
Oncogene HST
}

National Cancer Institute

\section{Source}

National Cancer Institute. Oncogene HST. NCI Thesaurus. Code C18462.

Human Oncogene HST is a mutated variant of FGF4 Gene (FGF Family) about $35 \mathrm{~kb}$ downstream of INT2 (same orientation), which encodes Fibroblast Growth Factor 4, a heparin-binding growth factor with homology to basic and acidic FGF. Gremlin relays an $\mathrm{SHH}$ signal from the polarizing region to the apical ectodermal ridge. Formin-dependent activation of BMP-antagonist Gremlin induces FGF4 and the SHH/FGF4 feedback loop. Oncogene HST disrupts normal cell function. 